\title{
Populism, Liberalization and Popular Participation: Industrial Democracy in Egypt
}

Assef Bayat

The American University, Cairo

While the mobilizing character of the populist movements and regimes in the Third World countries offers a great potential for the practice of grassroots democracy, the populist ideology and development strategy, at the same time, set certain serious constraints against genuine democratic practices. This theory is illustrated by a historical analysis of the experience of industrial democracy in Egypt under President Nasser and the subsequent regimes. Industrial democracy was designed to serve as a part of the populist strategy of mobilizing the working class in the post-revolutionary Egypt.

\section{Introduction}

The postwar period in the Third World has witnessed the emergence of 'radical' nationalist movements and regimes that while challenging Western colonialism have also been weary of Soviet-type communism. Such governments have enjoyed widespread popular support at home, and have manifested into a range of regimes from Peronist Argentina, Vargas's Brazil, Nasser's Egypt, Nyerere's Tanzania, Peru under General Velasco and the Islamic regime in Iran. This paper aims to discuss the structural constraints such populist regimes in the Third World countries face in sustaining democratic and grassroots organizations despite the fact that they set a ground for them.

By populist, we mean those Third World regimes which, by combining nationalistic ideology and development strategy hold the support of the 'popular masses' (including workers, peasants, the 'poor' and the petit bourgeoisie) as their social basis. Economically, these regimes pursue state capitalism (with emphasis on profitability and accumulation) within the framework of an authoritarian state form. In line with their nationalistic and 'anti-imperialist' ideology,

Economic and Industrial Democracy (SAGE, London, Newbury Park and New Delhi), Vol. 14 (1993), 65-87. 
these regimes are consolidated primarily by the national mobilization of the popular classes, or the 'people'. To this end, the 'people' are encouraged to mobilize and organize in various forms at national and local levels, in the workplaces, the state institutions, communities, neighbourhoods and corporatist associations. This mobilization offers a great potential for the creation or even extension of civil society, and the practice of grassroots democracy, as it sets a potential mechanism by which the people themselves can be involved directly in the process of decision-making in their concerned areas or associations. However, as this paper will argue, while this potential for empowering the grassroots remains a fact, populist regimes fail to provide the conditions for long-term actualization of grassroots democracy. In other words, whereas populism creates the possibility of mass mobilization and popular organizations, its ideology and development strategy come into conflict with genuine democratic practices. The populist projects and regimes, therefore, remain shortlived and lack continuity. The regimes tend to transform eventually into ones which lean on the propertied ruling classes and groups (instead of popular classes), functioning with a seemingly, if not genuinely, open political system (instead of a strictly one-party or noparty state), an open door economic policy (instead of one under state control) and close ties to the West (instead of being nationalist).

The above theoretical considerations are illustrated below by an historical analysis of the experience of popular participation in Egypt under President Nasser and the subsequent regimes. More specifically, I will base my argument on a discussion of the project of workers' participation initiated by the Free Officers in 1961 as a part of their strategy of mobilizing the working class by including them in the decision-making process in the vast public sector of the economy.

\section{The Initiative and Structure}

In 1952 a military coup brought the Free Officers, including Gamal Abdel Nasser, into power. The coup terminated the rule of King Farouk and the British military presence in Egypt. While the Free Officers seemed to be clear about their nationalistic plans (especially in terms of opposition to Israel and foreign domination), they lacked any coherent economic programme when they seized power. Only after a decade, in July 1961, al-Mithaq or the Socialist Charter was announced, representing the economic ideology and programme of 
the Free Officers. Following a massive populist campaign in July 1962, the Mithaq 'received the approval of 1500 delegates from the socalled popular forces, representing professional syndicates, labor and trade unions, agricultural cooperatives, and a host of other groups' (Ansari, 1986: 88). The Mithaq declared the 'Arab road to Socialism', and reflected a major reform policy including nationalization of all banks, insurance companies, basic and heavy industry, public works (Ansari, 1986: 87) and later, other 'egalitarian' measures such as free education, guaranteed jobs for university and high-school graduates, job security, health insurance and housing. The more fundamental reform policy, agrarian reform, was declared as early as 1952, but modified in subsequent years and began to be implemented in 1958 . The nationalization led to the emergence of a large public sector (accounting for some 40 percent of GDP) of which the 'public company' was the central unit. The 1966 Law defined the latter in terms of a group of employees who controlled public and state money which they were to utilize for production according to the national plan. These entities then spread over various fields of industry, agriculture, commerce, construction, transport and communication, business and fiscal activities (Zaalouk, 1989: 39). Although Egypt's development strategy seemed to be inspired by the socialist models of Eastern Europe, its brand of 'socialism' retained some fundamental virtues of market economies, including the profit motive and relative price flexibility (Handoussa, 1990: 202). This mixture of massive distributive measures combined with accumulation rationale and profit motive, and its authoritarian state form underlay Egyptian populism in the 1960s. Needless to say, this feature of the development model had a substantial impact on the labour movement, industrial relations and workplace democracy in Egypt.

Prior to the Revolution of 1952, Egypt's labour movement was relatively strong (by Middle Eastern standards) and had been organized along pluralistic lines with diverse allegiances to the nationalists, communists and Islamists (the Ikhwans). The labour movement played a significant part in the nationalist movements from the 1920s until Egypt gained its independence from Britain (Beinin and Lockman, 1988). Once in power, Nasser's regime strived to incorporate the union movement by suppressing the dissenting factions and rewarding the loyal ones (Bianchi, 1989). The process was completed between 1954 and 1964 when the Unified Labor Code (of 1956) and the Trade Union Law (of 1964) were passed (Bianchi, 1989: 128). At the same time, the regime empowered the movement in 
many ways by expanding it sectorially and strengthening collective bargaining. However, it restricted the activities of the movement by banning any incitement of class antagonism, the taking of industrial action, or trying to overthrow the political system (Bianchi, 1989: 125). Indeed a large segment of the movement was incorporated into the regime's structure, but at the cost of handsome concessions to both the union leaders and the rank and file of the movement. Workers' participation was one such concession.

Initially, the Law of public sector companies stipulated that one 'blue-collar' and one 'white-collar' worker be elected to the Board of Directors for a period of one year. However, the 1963 Law increased the workers' representatives on the Board (containing a maximum of nine members and meeting once a month) to four workers. The representatives, who were to be elected for a period of two years, were guaranteed protection by law against possible arbitrary measures by the employers (El-Sayed, 1978: 15-16). The chairman of the Trade Union Committee had the right to attend meetings of the board, but not the right to vote. By 1972 some 416 undertakings including 75 companies from the private sector had a management structure of this composition (Fahmi, 1979: 15). Several acts of legislation were stipulated with regard to the workers' participation project, the most recent one of 1983 aiming to 'overcome the shortcomings, conform with the changes in economic policies and promote efficiency' (Ayad, 1988: 2-3). In other words, with the prevalence of the open door economic policy after the death of Nasser in 1970, the new laws aimed to protect and encourage private investment, and to orient workers' participation exclusively to the public sector. The general framework of participation thus was defined at three general levels: the Project Board level, the Production Committee level, and participation in other forms including Personnel Committee, Grievance and Tripartite Committees (Ayad, 1988: 2-3). During Nasser's presidency, workers were to be represented also in the Arab Socialist Union, the National Assembly, and in the local and regional councils.

\section{Ideology and Impetus}

The underlying feature of workers' participation under the Nasserite regime was that it was initiated from above by the state. But what was the rationale behind this initiative? What was the origin of the idea? Did it materialize out of an ideological conviction or rather by certain 
pragmatic necessities? It seems that the origin of the strategy in Egypt was closely linked to the development strategy of the leadership.

Egypt seemed to have neither a traditional heritage (as in the Tanzanian institution of ujumaa, or familyhood) nor an ancient idea of participation (as in Latin American Catholic doctrine) to act as a basis for the articulation of its modern notion of industrial democracy. The idea, therefore, had to be invented. Indeed, most observers suggest that the Free Officers in Egypt had no clear idea about future political and economic arrangements when they seized power. Their populism developed only ten years after coming to power. What the Free Officers were clear about ideologically was their nationalism. This had been implanted by years of Egypt's colonial occupation as well as the Zionist occupation of the Arab lands. Thus, Nasser's early manifesto, Philosophy of the Revolution (1953), is merely a strong nationalist appeal for Arab unity. In terms of class location, the Free Officers' perception of world realities, like their underlying aspirations, 'were those of the middle-class milieu from which they had issued' (Aulas, 1988: 136). In short, it was a 'class in which the most diverse and contradictory ideologies, whether Islamic or Marxist in origin, are caught up and jumbled together' (Aulas, 1988: 136).

On the other hand, the Free Officers' approach to the labour movement indicated that they were certainly not democratic socialists. Indeed, by dismantling the old organs of control and surveillance, the coup of 1952 provided an opportunity for workers to express their demands more freely. This new movement, albeit not as widespread as the ones which have historically emerged during revolutionary periods, was concerned with such issues as the removal of old authoritarian managers, union recognition and better conditions. The most significant instance in this wave of labour unrest was the incident of Kafr al-Dawwar which occurred two months after the coup. Following a series of bloody confrontations between the police and the strikers, two workers' leaders were executed by the new regime (Beinin and Lockman, 1988: 421-6). Beinin and Lockman show that this and the ensuing incidents indicated the 'absolute hostility' of most of the Free Officers toward the independent action of the working class, and the communist ideology in the labour movement (1988: 431).

The Nasserite 'socialist' strategy was manifested in the announcement in 1962 of the al-Mithaq, or the Socialist Charter, which contained the policy of workers' participation. However, as Aulas 
has argued, the new policy came into existence, not from a concern for equality as such but for purely pragmatic reasons: it derived from an 'economic determinism' (choice of a development model) and 'strategic necessity', i.e. the US and European collusion with Israel forcing Egypt to ally itself with the Soviet Union (Aulas, 1988: 140; see also Hillal Dessouki, 1991: 260). Egypt was then to adopt a 'noncapitalist path of development' that the USSR would at the time prescribe for its Third World allies. Thus, Nasser's 'third-way development' became the 'non-capitalist road' (or rather state capitalism) plus nationalism. As a result, class perspective was replaced by general terms such as 'working together' and 'unity'. In political terms, the Nasserite project was marked by 'national democracy' in practice translated to mean state authoritarianism - a feature strikingly similar to Peru under the military (see Cotler, 1975; Gorman, 1982). In economic terms, it was 'no more than a Westerntype modernization' combined with the above mentioned political superstructure (Aulas, 1988: 142).

Here lay the contradiction. On the one hand, there was a need to mobilize the national resources by productive investment and by relying on technocracy and managerialism with all its attendant implications. On the other hand, there arose the need to mobilize the popular classes in order to build a popular following, especially since the bourgeoisie was considered incapable of mobilizing the national resources, and thus could not constitute a social basis for the military regime. These two tendencies, together with a strong nationalist appeal, constituted the populist ideology of the regime. Thus, the Arab Socialist Union, the sole legal party, technically became an organ for workers and peasants and 50 percent of the National Assembly was to come from these two classes (Clawson, 1981: 102). It was within this spirit that the programme of workers' participation was initiated. In July 1961 Nasser declared:

This principle [workers' participation] is extremely meaningful ... since the owner of the capital who builds a plant cannot operate this plant without the workers. The concentration of all managerial powers in his hands, in fact, represents social injustice. Accordingly, capital and labour must participate together in management. (El-Sayed, 1978: 16)

Workers' participation was intended to serve not only a political but also an economic purpose. It was hoped that the participation project would increase productivity, raise the income of the workers as a result of general improvement with regard to enterprise performance, 
and create an identity of interests between workers and enterprise as a whole (El-Sayed, 1978: 127). In short, workers' participation in Egypt resulted not so much from the leaders' ideological concern for industrial democracy as from some pragmatic political and economic imperatives. Nasserite populism was the ideological expression of these imperatives.

\section{Contradictions and Limitations}

To what extent, one must ask, was the project of workers' participation, adopted by the populist regime in Egypt successful in achieving its objectives in undermining militant unionism, bringing about industrial peace, higher productivity, social peace and national unity?

Patrick Clawson has suggested that the institution of participation, or the 'production committees', were originally set up in order to replace the trade unions which at times had resisted the regime's control (Clawson, 1982: 101). It is true that during Nasser's time, militant unionism was to a large extent curtailed, but this did not result from the activities of workers' participation. Indeed, the trade unions at the time had expressed reservations about any autonomous activities of the workers' representatives on the boards of directors. They even demanded that they be allowed to select or at least screen the elected workers' representatives. This request, however, was turned down by Nasser who wanted to exert greater control over labour activities by encouraging organizational rivalries in the workplaces. Thus, the unions and the managers were forced to share power with workers' representatives and the local Party committees (Bianchi, 1989: 138). In the end, militant unionism in Egypt was undermined not so much by the institution of workers' participation, but rather by Nasser's strong nationalist-populist appeal among the lay working masses, as well as his distributive measures which seemed to manifest the realization of his populist discourse.

As for the other objectives of the scheme, a study in 1974 concluded that 'workers' participation in management in Egypt, as expressed in Laws 114/1961 and 141/1963, [had] not attained its objectives' (ElSayed, 1978: 127). This was concluded by all parties involved in the programme: the workers, management, union officials, elected representatives and the government officials. But why did it fail?

Following a moderate annual growth rate of 3.5 percent during the 
1950s, the Egyptian economy experienced, in the second half of the 1960 s, serious problems including high inflation, decline in productivity and a drain of its national savings. Defence expenditures more than doubled to 10 percent of GDP in the early 1960s because of Egypt's involvement in the Yemen War (Handoussa, 1990: 205). Aid from the US and OECD was suspended, and that from the USSR and Eastern Europe was also significantly reduced. Public savings declined and current account deficit rose (to 4.5 percent in 1966 from 1.4 percent of GNP in 1960) (Handoussa, 1990: 205). War with Israel made the situation worse. Indeed, 'Egypt's focus on development virtually ceased in the aftermath of June 1967 war'. Attention instead was directed to the more immediate problems: destroyed cities and industries, war refugees, closed Suez Canal and the lost Sinai oil fields (Handoussa, 1990: 205).

All of these difficulties drew the government's attention to the acute problem of productivity in the economic front. As a consequence, according to Mark Cooper, the year of 1968 marked the beginning of economic liberalization when the concept of 'socialism' changed into 'efficiency and justice' (Cooper, 1983: 84). This meant that the government officially abandoned the idea of democratization in the sphere of production as the locus of change (which is to happen under socialism), focusing instead on that of distribution. The piecemeal transition from populism to capitalism which had already started under Nasser from 1968, gained a qualitatively new momentum with the coming to power of President Sadat in 1970. The advent of infitah, or the Open Door Policy, almost entirely altered the populist discourse by giving priority to foreign investment, free industrial zones, and the private sector. The practice, subsequently, followed. By this time, workers' participation, from the point of view of the state, was nothing but a piece of legislation. But what were the underlying causes of these limitations and ultimate failure?

It seems that the limitations and the eventual decline of the populist schemes of workers' participation in Egypt were not simply pathological, but structural. They resulted largely from the inherent conflicts of Nasserite populist projects in general, aided by the external constraints.

The first conflict related to that between the political/social basis of the state and its economic rationale. In other words, the aspirations of these popular classes to change the organization of production and their interest in extensive consumption measures came into conflict with the requirements of capitalistic development projects under 
taken by the state (i.e. discipline, productivity, reducing costs, technocratic values, bureaucratism and authoritarianism). In short, conflict resulted from an attempt to satisfy conflicting classes, that is, the popular classes on the one hand, and the bureaucratic and technocratic strata on the other. The fervent appeals by the regime to the popular masses (especially the workers and the peasants) provided them with a political sanction to encroach upon technocratic and managerialist values and rationale. They would tend, for instance, to oppose managerial discipline, hard work and low wages. This, however, conflicted with the productivist aspect of the development path. Indeed, the technocratic resistance to this project was manifested more in the decision of Aziz Sidqi, the Minister of Industry under Nasser, who organized a campaign against workers' participation (Bianchi, 1989: 136). On the other hand, the policy of guaranteed employment of university and high-school graduates (which was reflected in the growth of Civil Service employment by 39 percent by 1966) came into conflict both with the policy of saving and with import-substituting industrialization strategy which had little effects on employment. ${ }^{\prime}$ Thus, the individual enterprises were entangled by a contradiction of pursuing, on the one hand, efficiency and profit maximization, and on the other, social objectives including job security, selling at low fixed prices and industrial democracy.

In the difficult situation of choosing between 'egalitarian'/populist measures and 'economic growth/productivity', the regime eventually chose the latter. This would mean embarking upon a full-fledged capitalist development with its private and foreign variations as well as altering the social/political basis of the regime. The years following the presidency of Anwar Sadat saw the realization of these changes to which we shall return later.

The second conflict inherent in Nasserite development strategy with regard to industrial democracy was related to the rising expectations of the people, especially the working classes, and limited economic and political resources to meet them. The promises of Nasser, especially with regard to the workers' participation scheme, created such expectations among the workforce that it was as if 'the worker had become the true owner of the means of production, the master of machinery, the sharer in the profit and the partner in the management' (El-Sayed, 1978: 129-31). The objective reality, however, shattered these dreams. The power relations in industry never changed although the regime intended officially to empower the workers and the peasants in the decision-making processes concerning 
their work and public life; the management functions, attitudes and behaviour remained as authoritarian as before with the workers' representatives turning to a new bureaucratic stratum. 'This project [worker-participation in management]', stated a worker in 1974, 'is meaningless. The job of an elected Board member is a complete sinecure' (El-Sayed, 1978: 37). Another worker angrily further elaborated:

Do you think that the scarecrows we've dressed in men's clothing are going to suddenly start moving and talking? Believe it or not, the elected Board members are nothing more than a bunch of scarecrows. (El-Sayed, 1978: 37)

The managers' attitudes confirmed these ideas:

I was an army officer - and you know the role of the armed forces in the Revolution, in the protection of the rights of the people, and in the maintenance of socialist ideology in Egypt. I came here with the special mission of improving the firm. This is what I am doing and what I shall continue to do. I will not accept the idea that a group of illiterate workers can send a delegation to me to tell me how to do my job. And I assure you that I have told that to the government officials in the most emphatic way possible. (El-Sayed, 1978: 65)

The third conflict was that the authoritarian nature of the state came into conflict with the democratic principle of employee participation. To begin with, the regime never consulted the social groups who were to be directly involved in the project, such as the workers or the unions. In addition, the state initiated participation without recognizing the right to debate, disagree or criticize, since in a corporatist ideology and institution, the "unity of purpose and interest' does not allow for disagreement and dissent. The state consequently encouraged bureaucratism, favouritism and authoritarianism.

In a report from a debate conducted in 1965, "to which several progressive public sector directors and administrators were invited, it appeared that workers were not adequately and sufficiently represented in the administrative board' (Zaalouk, 1989: 40). This was attributed to the lack of adequate time for workers 'to attend political consciousness-raising and technical administrative training sessions - the result being that elections were carried out very much as before' (Zaalouk, 1989: 40). However, a more recent study showed that this shortcoming had less to do with the lack of time or 'political consciousness-raising' and more to do with the persistence of the 
same authoritarian division of labour in the workplace. The study was conducted between 1972 and 1974 and over 170 workers, as well as managers, union officials, workers' delegates and government officials were interviewed. The research stressed that the rank and file had basically been isolated from the scheme, since they could not place much input into the decision-making process in the enterprises, nor see any accountability on the part of their representatives. Thus, when asked to name any one of their representatives, over 60 percent of the workers were unable to do so (El-Sayed, 1978: 31). Over 85 percent believed that workers' participation had not achieved any of its objectives, and one out of three had no idea what these objectives were in the first place. They were convinced that their representatives had no influence on the decision-making ( 90 percent) or had only little impact (10 percent) (El-Sayed, 1978: 36). They even denied their representatives had much of a role to play at all from the start (ElSayed, 1978: 39).

The three contradictions and constraints cited above were not simply accidental, but were caused by the structural limitations of Nasserite 'socialism'. A meaningful popular participation would require strategic support of the state which would in turn involve political democratization at the state level and a transformation of power relations within the civil institutions, including the place of work. Secondly, it would require competence and consciousness on the part of the prospective participants. Empowering strategy (such as systematic educational and training measures, experiments, discussion and debate), therefore, would be a necessity. However, none of these preconditions were sufficiently met. The state failed to transform power relations at the workplace and, for that matter, in society at large in favour of the popular classes. In addition, the dearth of technically qualified personnel and competent lay workers added to the difficulties of effective employee participation (Zaalouk, 1989: 40; El-Sayed, 1978: 46-8). In the end, the workers' shattered dreams caused a high degree of dissatisfaction, apathy and low productivity.

As workers' participation failed to achieve its objective (of becoming a means of industrial peace, high productivity and political mobilization) the state employed a 'consumptive and distributive' policy (Cooper, 1983: 93-4) to attain the original objectives. Thus, Nasserite populism based itself upon massive incentives such a job security, education, health and housing. This certainly contributed to an early industrial peace, and to incorporating a significant 
section of the labour movement into the populist regime (Beinin and Lockman, 1988: 454 6). The distributive policy however, had its own internal contradictions. It came into conflict with the productivist and savings objectives of Nasser's economic development policy. From 1968 , the state tended towards making efficiency and productivity its prime aim at the cost of giving up distributive measures as well as workers' participation (Cooper, 1984: 94; El-Sayed, 1978: 131). The desire of the post-Nasser regimes to pursue this new policy, however, did not match their political capability to do so. But President Sadat's infitah, or Open Door Policy, certainly marked the beginning of a gradual departure from the old thinking.

\section{The Shift from Populism to Liberalism}

At least two factors triggered President Sadat to launch, immediately after the death of Nasser, his infitah, or Open Door Policy: the shortcomings of Nasserite populism, and the defeat in the 1967 war with Israel. As mentioned earlier, doubts had already been expressed about the economic failure of Nasser's distributive policy in favour of a productivist strategy based on a 'rational managerial system' and free market. But it was not until after the death of Nasser that President Sadat gained the opportunity to implement it. The infitah was officially legislated in 1974 under the October Working Paper, whereby private and especially foreign capital was encouraged by providing certain incentives such as free transfer of capital and remittances, tax holidays, free zones, favourable labour legislation, administrative assistance and the like. In addition, large-scale landholding was reintroduced, and some legal measures were carried out to return the properties sequestrated during the Nasser era.

Internationally, the regime distanced itself from the USSR in 1973 in a dramatic policy change, and a rapid rapprochement and later close alliance with the West, in particular the USA, was made. The change in the regime's economic strategy and its foreign policy inevitably affected its domestic social basis and political alliances. Instead of the popular classes, Sadat's support came from the business communities, the class of 'new rich' which rapidly grew in the 1970 s, as well as from his international allies. In short, the whole populist rhetoric began to be replaced by a new social discourse based upon notions of individual achievement, hard work and competition. This was reflected in his relationship with the labour movement. 
Unlike Nasser, President Sadat lacked grassroots support within the working class. He therefore needed the support of the leadership of the labour movement to carry out his new policies. The regime 'tried to transform the top of the Union hierarchy into a selfrecruiting elite with broad power of consultation in economic policy making' (Bianchi, 1989: 129). Turnover in the leadership of the union bureaucracy fell sharply and was nil in the union election of 1983 (Bianchi, 1989: 129). The national labour leaders continued to become simultaneously government officials or agents of the ruling (National Democratic) Party.

Yet the labour movement continued to grow; union membership was redistributed across economic sectors and geographical regions. In 1987, the Egyptian Trade Union Federation (ETUF) consisted of 23 trade unions ranging from industry, services and agriculture to military production, with well over three million members (ETUF, undated: 15). The ETUF controlled a Labour Bank and a Workers' University (set up in 1985), a non-degree institution which provides training and education to the trade unionists in various languages, technical and managerial fields. Internationally, ETUF became an active member of OATUU and of ICATU and ALO (the Arab Labour Organization). However, the rank and file remained distant both from the labour leadership and the government. The frustration of the lay working people was reflected in the various wildcat strikes and urban riots carried out in the 1970s and the 1980s.

The decade of the 1970s witnessed major labour protests, including strikes at the Textile and Cable Works in Mahala in 1975, the Alexandria and Port - Said shipyards, the Eastern Tobacco Company, and the strikes of the bus drivers in Cairo in 1976. A major strike at the Misr Spinning and Weaving factory in Mahala al-Kubra about overtime pay and conditions left 50 workers dead and 2000 arrested following the occupation of the factory and confrontations with the security forces. ${ }^{2}$ But more significant were the January 1977 riots which initially appeared to be started by workers in Harir factory in Hilwan and transport workers in Alexandria, as a reaction to the reduction of subsidies (pressed by the IMF), and which spread throughout the country. Massive and at times violent demonstrations occurred in the major cities involving workers, students and the urban low-income groupings. Among the slogans was 'Nasir always said: "Take Care of the Workers"' (Posusney, 1990: 8). Some 79 protesters were killed during these riots, and over 1200 arrested (Baker, 1978: 165). While 
condemning violence, the ETUF leadership, under heavy pressure from below, supported the workers.

Following a short period of industrial peace in the late 1970s and the early 1980 s (due to a combination of repression, relative wagerise, and the out-migration of millions of Egyptian workers to the Gulf states), a new upsurge of unofficial labour unrest began in 1983. This included protests in Nasr Pipe Manufacturing Company in Hilwan, Saqa factory in Cairo, Daqhakiya Textile Plant, Shubra Company for Engineering Products (a war production plant), a sewage plant in Aswan and a chemical plant in Suez. The industrial actions involved plant occupations, sit-ins and stoppages ending either by a management promise to meet demands or by the raid of the security forces into the seized workplaces. Among these, the 1983 sit-in at Hilwan Light Transport Factory was particularly violent. Demanding a nature-of-work compensation, the workers staged a sit-in at the plant which eventually ended when the security forces, armed with tear gas, clubs and electric prods, broke up the occupation. In 1984, a new law, supported by ETUF leadership, authorized doubling workers' contribution to health and insurance pensions. This triggered a series of violent strikes and street riots in a number of industrial areas in the country. In Kafr al-Dawwar where the incident was combined with the rise in the price of some subsidized items, the workers and other urban people cut telephone lines, blocked transportation, destroyed rail cars and shouted slogans against the government and the labour movement leadership. The confrontation came to a halt when President Mubarak repealed the price increase on some food stuff. This incident left three dead and over 120 arrested. Yet sporadic stoppages continued in the following years in a number of plants in Shubra al-Khaima, Misr-Iran Textile Company in Suez, Abu-Kir munitions plant in Alexandria, which culminated in the prolonged strikes of workers at Esco and Mahala al-Kubra in 1985 and 1986.

Although in certain cases workers were supported by the local union officials, they almost entirely acted on their own - mostly against the wishes of the ETUF officials. Despite this divergence, both the rank and file and the leadership of the labour movement shared a common interest in maintaining the concessions they had won during the populist era.

Thus, despite the Open Door policy, the economy was still dominated by the vast public sector which remained virtually intact, simply because the new regime lacked adequate legitimacy to undo 
Nasserism entirely. The labour movement, therefore, retained much of the achievements of the Nasserite era, including rent control, job security, subsidies, free medical care and education, working-class housing and various other bonuses. The quality of some of these services, such as medical care and education, however, began to decline.

Although it was excluded from the private sector, the workers' participation scheme persisted in the public sector enterprises which still accounted for some 40 percent of GDP and 50 percent of the nonagricultural labour force: In the post-Nasser era, various acts of legislation came into existence in order to amend the scheme. The Egyptian Constitution of 1971 supported the participation of workers in the management and profits of the public sector companies. Article 26 made it clear that 'Workers shall be represented on the boards of directors of the public sector units by at least $50 \%$ of the number of members of these boards'. The Constitution also guaranteed 'for the small farmers and small craftsmen $80 \%$ of the membership on the boards of directors of the agricultural cooperatives and industrial co-operatives' (Article 26). Since then various acts of legislation have been introduced with regard to the public sector companies, which indirectly affect the policy of employee participation. A 1983 law (Law 97), for instance, authorized the establishment of Public Sector Bodies to participate in developing national economy and to achieve development policy according to general state planning. However, by the end of the 1980 s, it became clear that the main debate was not about enhancing participation, but reforming, rationalizing and even privatizing the public sector. Law 203 in 1991 thus legally authorized some degree of enterprise autonomy in the public sector and the implementation of the rationalization policy. Although the employee participation scheme was not altered, the new law indirectly limited the scope of industrial democracy. ${ }^{3}$ In addition, the privatized enterprises were excluded from the provisions of the workers' participation policy.

\section{Industrial Democracy in the Open Door Era}

If, as we argued before, popular and workers' participation manifested the populism of the Free Officers and served to extend the popular social basis of the Nasserite regime, why did it continue even 
after the populist era came to an end? And, how would it fit into the more technicist and productivist ideology and strategy of the postNasser regimes, when managerial prerogative was conceived of as solely responsible for high productivity?

There is evidence that the regimes did wish to do away with the scheme altogether, but were simply unable to do so. A number of factors were involved. First, 'workers' participation' was a constitutional issue, and it could not easily be removed legally. ${ }^{4}$ Secondly, there has always been a resistance on the part of the labour movement, both by lay activists and more emphatically, the trade union leaders, against revoking the policy. The lay activists see in the scheme a legacy of Nasserism which is reminiscent of distributive measures and populist/nationalist discourse - one which is regarded as having granted the working people socio-economic gains, and a measure of dignity and social significance. In addition, for the rank and file, the workers' participation policy serves as a potential organizational mechanism to counter the union bureaucrats.

In similar situations, trade unions normally are opposed to the idea and practice of workers' participation which they consider a rival counterpart. Numerous examples from experiences in India, Portugal, Peru and Tanzania illustrate this conflict of interest (Bayat, 1991). Expectedly, the conflict may occur only if the institution of workers' participation remains independent from the trade unions.

However, in Egypt, the trade union leadership wants to retain the scheme of workers' participation. This is so because the unions have been able to dominate the workers' participation institutions: in most cases the workers' delegates on the board of directors are the local union leaders. Therefore, they have a vested interest in the scheme; and so long as the workers' participation institutions remain incorporated in the union structure, they wish to maintain it. Below I shall discuss what benefits the workers' participation structure brings to the workers' representatives and union officials. On the other hand, the government has conceded maintaining the policy in exchange for the support it needs to get from top union officials in pursuing its economic liberalization policies.

The third reason behind the survival of workers' participation in the post-populist era is that it has largely been devoid of an effective and meaningful content. In most enterprises the policy exists only formally. My observations in Egypt in 1988-9 attested to this conclusion. The findings resulted from interviews with a number of workers' representatives on the board of directors in the Egyptian 
public sector companies, the officials of the Workers' University, trade unionists and lay workers.

A meaningful workplace democracy means a genuine participation of not merely the delegates, but also the ordinary employees in decisions concerning the various aspects of their work and work relations. This does not, of course, imply that all employees directly take part in the board of directors. Rather it suggests an organizational and procedural mechanism whereby the ordinary members are able to provide their freely-elected representatives with input, and simultaneously demand accountability from them. In the Egyptian experience, the rank and file neither seem to have much idea nor care about a scheme for workers' participation. This appears to result from the fact that they are neither involved in nor affected by this policy. For them, 'participation' is the privilege of an elite group of employees. The workers' representatives on the board of directors do not normally report the results of their discussions with management to their members. The explanations of this vary. Some workers' delegates do not see the need to do so, 'because', they pointed out, 'the discussions are secret'. A worker delegate put it quite bluntly:

The board of directors has specific responsibilities. These responsibilities are both executive as well as organizational. The rank and file should not know about these matters. They should be allowed only to know about decisions concerning profits, incentives and similar issues, because this is all that interests them. Moreover, they will not be able to comprehend the strategies and plans of work.

In addition, it was commented, "each industry has its own secrets, just like armies', and these should not be disclosed to the public. Finally, even if there were a desire on the part of some workers' representatives to inform their members about the result of their discussions on the board, formal communication with fellow workers is lacking. In fact, any kind of assembly by the workforce in the workplace for any purpose is 'forbidden according to law'. This restricts one of the most fundamental requisites for the practice of workplace democracy - free discussion and flow of information between the rank and file and their representatives.

Consequently, most workers' representatives have come to constitute an elite group within the workplaces. Representation on the board of directors is conceived by them as a privilege bestowed by law, ability, charisma and education. A large majority of the representatives in my study were white-collar workers with a high degree of status consciousness who had frequently been appointed to 
the office. The representatives stated that they normally 'do not have any disagreements with the managers in the board of directors'.

In short, for a large group of workers, the scheme did not hold much significance. For the representatives, it appeared to serve mainly as a vehicle for increasing status, a place for gaining experience and skill and, perhaps more importantly, a way to cultivate connections. Lack of interest in a genuine workers' participation may be revealed by looking at the educational material available in the Workers' University. A report on this topic stated that

The educational material contains texts which present the respective laws, giving an explanation, or deal with tangible matters, for instance management system. Less attention is given to aims of participation, respectives of participation, relations between workers' participation and trade unions, theories of workers' participation etc.' (Kester, 1990)

\section{Some Exceptions?}

The above discussion, however, does not intend to claim that genuine interest in industrial democracy has totally given way to apathy and co-optation. Indeed some evidence points to the serious interest some workers exhibit in the idea. The sit-down strike in 1989 in the Iron and Steel Company in Helwan, Egypt's largest factory complex, displays the extent to which some employees take the idea of workers' participation seriously. The strike initially began when management refused to comply with workers' demands for higher allowances. Two workers' representatives on the board of directors (composed of nine members) refused to accept the board's decision, encouraging workers to push for their demand. As a consequence, these two representatives were sacked from the company by management. The second sit-in which involved some 16,000 workers was entirely focused on the issue of the reinstatement of the two workers' representatives. Security forces thus stormed the factory where at least one worker was killed, more than a dozen wounded and some $500-600$ were arrested. $^{5}$

What seems to distinguish the nature of workers' participation in this complex from other cases, according to a worker, are that the workers' representatives on the board attempt to retain their autonomy from the management and the Union Committee in the company; they do share the discussions on the board with their fellow 
workers. As no formal means of communication exists, the workers' representatives resort to informal methods of informing their colleagues of news and getting their input. Communication exists, for instance, in the workshops, hall-ways or at the bus stops. The workers, as a consequence, are keen about the fairness of elections, and take care not to allow any election rigs, or interference from the Ministry of Labour. In this way some kind of a tradition of militancy has developed in this complex which seems to have contributed to maintaining a degree of fair representation on the board. ${ }^{6}$

It follows that, in general, a major obstacle to an effective participation in the workplace stems from a variety of state interference with workplace or enterprise politics. The state has constantly used its legal right of supervision to undermine the autonomy of the syndicates (Kandil, 1991). The state may use the same power to remove the leading candidates from the electoral lists, ensuring that more conformist candidates get elected. It fears that autonomous workers' delegates on the boards might undermine the power of management. It is perhaps this fear that has led the government to consider seriously a proposal bringing an end to the practice of electing workers' and employees' representatives to boards of directors.

In 1989 a heated national debate began on the fate of the public sector companies. An interest in privatizing the public sector had already been expressed publicly long before, in the 1970s. But the new round of discussions occurred against a background of the mounting strength of the private entrepreneurs, as well as the increasing Egyptian debt problem which by 1989 was estimated to have reached $\$ 50$ billion.

The pressure for economic liberalization, therefore, came from both the internal power block and the commitment of the Egyptian government to the programme of stabilization advocated by the World Bank against Egypt's debt payment rescheduling. The end result consists of a package of privatization and/or reform of the public sector which calls for, among other things, freedom of pricing and allowing management a free hand in laying off and disciplining workers (Al-Sayyid, 1990: 42). The reform also includes the removal of the workers' participation scheme.

The top leadership of the ETUF has already declared its willingness to co-operate with the public sector reform. It has, however, expressed reservations against the privatization option. The opposition of organized labour to privatization is based upon the well- 
founded fear that, at least initially, it would weaken workers' purchasing power, cause massive lay-offs, reduce union membership and thus undermine their bargaining power within the Egyptian political system (Al-Sayyid, 1990: 42).

In these national debates about reform and privatization, the labour leaders have, in general, argued for the continuation of the practice of 'workers' participation' within a tripartite structure. It seems that the policy continues under the new public sector law (203/ 1991). However, whether it will survive the liberalization policy in the future remains to be seen. It will depend upon two factors at least: the ability and interest of the labour movement in maintaining it, and the degree of its effectivness and meaningfulness.

\section{Conclusions}

The Egyptian experience of industrial democracy under Nasser and subsequent governments shows that populist ideology tends to furnish some degree of objective ground for grassroots participation in decision-making in the economic sphere. Yet, at the same time, it restricts, transforms and distorts the practice of participation, turning it into a pragmatic means of mobilizing a segment of the society upon which the (nationalist) regime can rest. This derives from some inherent contradictions of populist development strategy in general, i.e. the contradiction between the increased political and economic expectations of the popular classes, and the limited resources available to satisfy them; between the practical implications of populist ideology (e.g. consumption measures, political mobilization, etc.) and the productivist strategy pursued (exemplified in discipline, saving, profitability requirements, technocratic rationale, etc.); and finally between the authoritarian nature of the populist state and the democratic thrust of popular participation. These contradictions tend, in the long run, to restrict and undermine the practice of grassroots participation, including industrial democracy. The potential institutions of participation, of popular control, instead become corporatist organizations of the state. They invariably lack autonomy and initiative of their own.

It seems, therefore, that only a guarantee of organizational autonomy and pluralism may turn the massive mobilization of the populace in these countries into a ground for genuine grassroots democracy and direct involvement of the people in their own affairs. I 
am, in fact, referring to popular participation within a democratic structure, which in effect implies transcending populism. But this is not a straightforward strategy. Serious questions remain. How far, for instance, within the pluralistic structure, do market forces restrict grassroots participation in the economy and the polity? In the same vein, the Egyptian experience indicates that while liberalization of the economy and polity potentially may remove the populist constraints on autonomous organizations within the civil society, there is no automatic guarantee that non-governmental mobilization will necessarily be autonomous and democratic. Indeed, paternalism and corporatism may still continue, albeit on a different scale and form. In addition, in free market conditions, individual enterprises may allow industrial democracy only to a limited degree when it brings them high productivity and industrial peace and when it is assured that relations of control will not be altered. Beyond that, participation is considered as an encroachment into the managerial prerogative. Ironically while the practice of 'participation' is limited only to the sphere of economy and more specifically to the workplace (with the sphere of polity being monopolized by an individual, group, party or a movement) for the authoritarian populists, the liberal concept of participation is restricted solely to the sphere of polity and rarely applies in economic decision-making. This confirms the long-held argument that the liberal concept of democracy contains a major flaw, in that the majority of the people are deprived of the means to influence effectively the decisions concerning their working life.

\section{Notes}

The author acknowledges the American University in Cairo Press for permitting two excerpts taken from El-Sayed's Workers' Participation in Management: The Egyptian Experience (1978). The author is grateful to Professors Heba Handoussa and Jalal Amin, of the American University in Cairo, and Professor Mustafa Al-Sayyid, of Cairo University, for their comments and criticisms on the earlier version of this paper. It goes without saying that $\mathrm{I}$, alone, am responsible for any misjudgement this article may contain.

1. Personal communication with Professor Handoussa; see also Handoussa, 1991: 205.

2. On the reports of workers' protests in the 1970 s and 1980 s, I have relied heavily on Posusney, 1990.

3. The law, for instance, stipulates that the General Assembly of the Holding Company has the power to sell all or part of the subordinate company (where 
employee participation operates), even if this decision reduces the public shares of the company to less than 49 percent. In such circumstances, workers' representatives would have no right to intervene. This interpretation is based upon a lecture on the 'New Public Sector Law' given by Mahmoud Fahmy, an Egyptian expert on the public sector law, at the American University in Cairo, 3 February, 1992.

4. I am grateful to Khalid Fahmy for bringing this point to my attention.

5. Editorial, Middle East Report, 161 (1989); K. Abbas et al. (1989); also interview with an eyewitness.

6. Interview with a local leader. The eyewitness also points to the Misr Textile Company as a successful experience in fair representation. An important factor is said to be the close co-operation between the Union Committee and the workers' representatives on the Board.

References

Abbas, K. et al. (1989) Malhamlat al-Hadid wa al-Solb: August 1971-August 1989. Cairo: n.p.

Al-Sayyid, M.K. (1990) 'Privatization: The Egyptian Debate', Cairo Papers in Social Science 13(4): 1-62.

Ansari, H. (1986) Egypt: The Stalled Society. New York: State University of New York Press.

Aulas, M.C. (1988) 'State and Ideology in Republican Egypt: 1952-1982', in F. Halliday and H. Alavi (eds), State and Ideology in the Middle East and Pakistan. London: Macmillan.

Ayad, A.S. (1988) 'Workers' Participation in Management: The Egyptian Model', paper presented at the International Round Table on Workers' Participation and Trade Unions in Conditions of Contemporary Technological Change (12-15 September), Belgrade.

Baker, R.W. (1978) Egypt's Uncertain Revolution under Nasser and Sadat. Cambridge: Harvard University Press.

Bayat, A. (1991) Work, Politics and Power. New York: Monthly Review Press; London: Zed Books.

Beinin, J. and Z. Lockman (1988) Workers on the Nile. New Jersey: Princeton University Press.

Bianchi, R. (1989) Unruly Corporatism: Associational Life in Twentieth Century Egypt. Oxford: Oxford University Press.

Clawson, P. (1982) 'The Development of Capitalism in Egypt', Khamsin 5: 77-111.

Cooper, M. (1983) 'Egyptian State Capitalism in Crisis. Economic Policies and Political Interests', in T. Asad and R. Owen, (eds), Sociology of Developing Societies: The Middle East. London: Macmillan.

Cotler, J. (1975) 'The New Mode of Political Domination in Peru', in A. Lownthal, (ed.), The Peruvian Experiment: Continuity and Change under Military Rule. New Jersey: Princeton University Press.

El-Sayed, S. (1978) Workers' Participation in Management: The Egyptian Experience. Cairo: The American University in Cairo Press.

ETUF (Egyptian Trade Union Federation) (undated). Cairo: ETUF Press.

Fahmi, M. (1979) Ishtirak al-'Unnal fil-Idara fi Msir: Darasat al-midaniyva (Workers' Participation in Management: a field study). Cairo: Cairo University Press.

Gorman, S. (ed.) (1982) Post-Revolutionary Peru. The Politics of Transformation. Boulder: Westview Press. 
Handoussa, H. (1990) 'The Impact of Foreign Aid on Egypt's Economic Development, 1962-1986', pp. 195-224 in U. Lele and I. Nabi, (eds), Transitions in Development: The Role of Aid and Commercial Flows. San Francisco: Institute for Contemporary Studies.

Hillal Dessouki, A.E. (1991) 'The Public Sector in Egypt: Organization, Evolution and Strategies of Reform', in H. Handoussa and G. Potter (eds), Employment and Structural Adjustment: Egypt in the 1990s. Cairo: The American University in Cairo Press.

Kandil, A. (1991) 'Socio-Economic Policies and Interest Groups in Egypt', unpublished paper presented at the Conference of Socio-Economic Transformation, State and Political Regimes in Egypt and Turkey (24-25 May), Cairo.

Kester, G. (1990) 'Summary Report of the Visit to Egypt, March 30-April 6', unpublished report.

Middle East Report (1989) 'From the Editors', 161: 2-3.

Nasser, G.A. (1953) Philosophy of the Revolution. Cairo: El-Dar al-Qowmiyya alTaba'a wal-Nashr.

Posusney, M. (1990) 'Egyptian Workers' Struggles During the Infitah Period: Their Nature and Historical Roots', paper presented in the Workshop on Middle East Labour and Working Class History: Concepts and Approaches (12-13 April), Center for Middle Eastern Studies, Harvard University.

Zaalouk, M. (1989) Class, Power, and Foreign Capital in Egypt. London: Zed Books.

Assef Bayat
is Associate Professor of Sociology at the
American University in Cairo, Egypt and
is particularly interested in Third World
political economy, labour and
development, popular participation and
political sociology. He is the author of
Workers and Revolution in Iran (London:
Zed Books, 1987), Work, Politics and
Power (New York: Monthly Review
Press; London: Zed Books, 1991), and
several articles. He is currently preparing
a book on the 'Politics of the Marginal
Poor in Iran: 1975-1990'.

